GLOBAL JOURNAL OF EDUCATIONAL RESEARCH VOL 14, 2015: 141-147

COPYRIGHTC BACHUDO SCIENCE CO. LTD PRINTED IN NIGERIA. ISSN 1596-6224 www.globaljournalseries.com; Info@globaljournalseries.com

\title{
ASSESSING PARTICIPATION IN SECONDARY EDUCATION QUALITY ENHANCEMENT: TEACHERS, PARENTS AND COMMUNITIES IN CROSS RIVER STATE
}

\author{
C. O. UKPOR, I. M. AKUBUIRO, P. U. BASSEY AND A. E. OKON
}

(Received 12, September 2011; Revision Accepted 24, October 2014)

\begin{abstract}
The study examined some factors responsible for low participation of teachers, parents and communities in quality enhancement of secondary education in Cross River State, Nigeria. Teachers and parents of students in public secondary schools were used. A total of 8,590 subjects constituted the population of the study. However, only 840 teachers and 100 parents i.e. 940 subjects formed the sample from where data were obtained through questionnaires and interview methods respectively. Twenty (20) indicators of reasons for low participation of stakeholders in school affairs were built into the questionnaire. A survey design was adopted and multistage sampling technique was used. Teststatistics used for data analysis were weighted mean (X) and standard deviation (SD), and a mean score of 2.5 and above formed the level of significance/acceptance. The findings indicated poor motivation of teachers, inadequate school facilities, unrealistic pupils assessment, poor knowledge of subject matter and inadequate supervision as teachers factors, while large family size, state and national ailing economy, low moral values and philosophy of the end justifies the means were reasons for low parents and communities involvement in secondary education-quality improvement. It was recommended that the quality of instruction in teachers training institutions be improved, as well as intense public enlightenment programme were among the recommendations made.
\end{abstract}

KEYWORDS: Participation, quality, enhancement, parents-teachers-association and communities.

\section{INTRODUCTION}

The success of any educational programme is often associated with active involvement of different stakeholders and the enabling environment for the citizens to actualize the programme contents. In 2000 a forum of different countries was held in Dakar whose focus was ways to improve quality of education among other targets (Ereyinmwen \& Ezeanah, 2011). To achieve this synergy in the quality of secondary education, teachers, parents and communities ought to participate effectively in their respective capacity in school related activities.

The teacher's role in enhancing the quality of education is quite crucial since learning in the school system does not occur in a vacuum. Perhaps, this is the basis of the axiom that a nation cannot rise beyond the level of its teachers as stated in the National Policy on Education (FRN, 2004).

Isangedighi (2007) asserted that the concern on standard of education hinges on the quality of instruction the children are receiving, the level of teachers devotion, the quality of

C. O. Ukpor, Department of Educational Foundations, Guidance and Counselling, University of Calabar, Calabar, Cross River State, Nigeria.

I. M. Akubuiro, Department of Educational Foundations, Guidance and Counselling, University of Calabar, Calabar, Cross River State, Nigeria.

P. U. Bassey, Department of Educational Foundations, Guidance and Counselling, University of Calabar, Calabar, Cross River State, Nigeria.

A. E. Okon, Department of Educational Foundations, Guidance and Counselling, University of

Calabar, Calabar, Cross River State, Nigeria. 
learning environment as well as motivation of the learner. Ibrahim (2013) views access to quality education as part of fundamental human rights to children which serves as a gateway of improved standard of living, foundation for nation's economic development for future growth, and added that this can be made possible where adequate, functional and suitable resources (teachers) are made accessible to all, including vulnerable children.

Egwuasi and Okoro (2011) opined that for effective classroom delivery of subject matter and the production of psychologically balanced Nigerian job seekers, a prospective teacher must have a basic teaching qualification of the Nigeria Certification in Education (NCE) at the preprimary and primary school levels, while a bachelor degree should be the minimum qualification at the secondary school level. They added that in addition to paper qualification a would be teacher should prove to have possess sound knowledge of the subject matter.

Etuk (2002) asserted that professional groups are judged by their members, therefore the teaching profession cannot be a dumping ground for never-do-wells, hence, there should be a high selective method of recruitment of prospective entrants. In addition to the possession of high paper qualification, the teacher must be self-organized, have willingness to learn new things, and have large share of individual responsibility (Idiong, 2001). Scheerens (2000) stated that for effective and improved schools, teachers and school heads should be made to participate actively in basic and simple form of school self-evaluation in collaboration with external support, which he described as innovatory process.

Brunner's theory of instruction (1966) gives credence to the invaluable contribution of teachers in learning improvement. The theory holds that all children have a built in "will-tolearn", that is, intrinsic motivation, which moves them to learn. He classified the intrinsic motivations as curiosity drive, competence drive and reciprocity drive, which are rewarding in themselves. Brunner suggested that teachers must arouse and regulate their students' exploration of knowledge. It is the teachers' responsibility to help students to realize that guided exploration is more meaningful and rewarding than spontaneous learning they achieve in short run (National Teachers' InstituteNTI, 2000). This implies that teachers have a duty of helping students under their care to achieve maximally. The teachers can only help the students by being active participants in the business of teaching.

The home is the child's first contact with the wider environment. The home refers to the parents and other members of the family. A child's parents are meant to play supportive role to the school in terms of everyday care of the child and his/her education. Essien (2006) puts it that the family plays a leading role in transmitting the values of society to the child. It is through their active participation in the daily events of the family life that the children are expected to learn to value property, laws and orders, to avoid bad company and to be loyal to family and society.

Children come to school from various background, some come from very poor homes while others have well-to-do parents. Children who come from well-provided homes and where parents understand their roles as caregivers tend to have an early advantage over those from poor homes (Isangedighi, 2007).

Parents sometimes influence their children education by collaborating with the school as a group of individuals called ParentsTeachers-Association (PTA). The Parents Teachers Association is a welfare organization whose primary objectives include the following:

To provide effective link between the home and the school; to show interest and concern in school affairs so as to ensure achievement of high academic and moral standard; to assist in providing certain facilities; to encourage the participation of the local community in the education of their children/wards; and to encourage cooperation and understanding between parents, teachers and students for the progress of the society (Presbyterian Church of Nigeria Schools PCNS, 2004).

In a study on assessment of emerging roles and responsibilities of communities toward vocational skills acquisition, Abubakar and Lawan (2011) attempted to explore ways of improving National Open Apprenticeship Scheme (NOAS) in Nigeria. They sampled 22 community members, collected data from them through structured questionnaire. The data were analyzed using percentages. It was revealed that 67 percent of respondents noted that parents do not participate fully in their children enrolment and training.

The social context in which school learning occurs is also an important factor in quality enhancement. Many times one finds that 
the larger society emphasizes other values which do not sustain the work of the school. For instance, it is a common impression young people imbibe from local leaders who often 'say and do' that it does not pay for one to spend a long period schooling.

Olugbide (2013) reproved that the society should not celebrate people with questionable character. He said, "No thanks to the way and manners celebrated icons with no moral values are being respected in Nigeria" (Punch, July 16. P.46). Often some people who have low education get more money and recognition in the society than the highly educated ones and the society hardly finds out the sources of their riches.

Ornstein and Levine (2006), suggested that communities should encourage improvement of education by spreading messages like: "If you stay in school, work hard, and master the basic, you will be helped to find a job". They added that communities should be involved in education by awarding scholarship, encouraging privatization of schools, and to encourage corporate institutions to invest in secondary education.

\section{Statement of the problem}

The federal and state governments have taken some steps to improve the quality of secondary education in Nigeria by increasing the number of educational institutions, raising minimum teaching qualification, training of more teachers and lots more. However, there is observed frequent occurrence of low participation of teachers, parents and communities towards improving secondary education quality. This scenario is of great concern to all-well meaning individuals and institutions. The question now is: What are responsible for the low participation of teachers, parents and communities in secondary education quality enhancement in Cross River State, Nigeria?

\section{Purpose of the study}

The study determined the causes of low participation of stakeholders in secondary schools in Cross River State. Specifically, the study:

i. Determined reasons for low participation of teachers in secondary schools in Cross River State;

ii. Examined reasons for low involvement of parents in secondary schools in Cross River State; and iii. Examined reasons for low participation of communities in post-primary schools in Cross River State.

\section{Research questions}

the study:

The following research questions guided

i. Why is there low participation of teachers in quality enhancement of secondary education in Cross River State?

ii. Why is there low participation of parents in quality enhancement of secondary education in Cross River State?

iii. What is responsible for low participation of communities in quality enhancement of secondary education in Cross River State?

\section{Methodology}

The study adopted a survey design. Cross River State has three educational zones with a population of 264 public secondary schools and 8486 teachers. The sampling technique was multistage. Stratified sampling was used to select 10 percent of the 264 schools (26) and 10 per cent of the 8486 teachers (849). The educational zones formed the strata. In each of the sampled schools, 4 parents were selected by purposive or judgemental sampling procedure to give a total of 104 parents.

The study used structured questionnaires to collect data from teachers and interview was used to elicit information from parents. A total of 840 questionnaires were appropriately filled and returned out of 849 administered while 100 parents were interviewed. The instruments were given face and content validity and were trial tested using test-retest method. A correlation index of 0.86 was obtained through split-half analysis. A five-point rating scale of 5-1 was adopted for both questionnaire and interview.

The test statistics employed for data analysis were weighted mean $(\bar{X})$ and Standard Deviation (SD). A weighted mean of 2.5 and above scored by respondents indicated acceptance to the respective statements in Tables 1 to 3 . For obvious reasons, private secondary schools were not included for this study.

\section{Results and discussions \\ Research question 1}

Why is there low participation of teachers in quality enhancement of secondary schools in Cross River State? 
Table 1: Weighted mean $(\bar{X})$ and standard deviation (SD) of teacher and parent opinions on why there is low participation of teachers in quality enhancement in secondary education in Cross River State (No. of teachers $=870$ and no of parents $=100$ ).

\begin{tabular}{|c|c|c|c|c|c|c|c|c|}
\hline \multirow[t]{2}{*}{ S/No } & \multirow[t]{2}{*}{ Reasons } & \multicolumn{2}{|c|}{ Teacher } & \multicolumn{2}{|c|}{ Parents } & \multicolumn{2}{|c|}{ Grand mean } & \multirow[t]{2}{*}{ Decision } \\
\hline & & $\bar{X}$ & SD & $\bar{X}$ & SD & $\mathrm{G} \bar{X}$ & SD & \\
\hline 1. & $\begin{array}{l}\text { Teachers are poorly } \\
\text { motivated }\end{array}$ & 4.50 & 0.60 & 3.80 & 0.70 & 4.15 & 0.69 & Accepted \\
\hline 2. & $\begin{array}{l}\text { Teachers } \\
\text { knowledge } \\
\text { matter }\end{array}$ & 2.00 & 0.67 & 3.50 & 0.60 & 2.75 & 0.63 & Accepted \\
\hline 3. & $\begin{array}{l}\text { Inadequate instructional } \\
\text { supervision by principals }\end{array}$ & 2.06 & 0.69 & 3.04 & 0.60 & 2.55 & 0.70 & Accepted \\
\hline 4. & $\begin{array}{l}\text { Inadequate supervision } \\
\text { by school } \\
\text { supervisors/inspectors }\end{array}$ & 2.06 & 0.98 & 3.65 & 0.70 & 2.85 & 0.87 & Accepted \\
\hline 5. & $\begin{array}{l}\text { Poor relationship } \\
\text { between teachers and } \\
\text { students. }\end{array}$ & 1.90 & 0.80 & 2.40 & 0.87 & 2.15 & 0.91 & Not Accepted \\
\hline 6. & $\begin{array}{l}\text { Low professional } \\
\text { qualification of teachers }\end{array}$ & 0.06 & 0.01 & 2.40 & 0.30 & 1.23 & 0.16 & Not Accepted \\
\hline 7. & 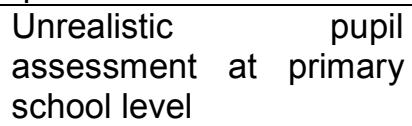 & 3.60 & 0.66 & 3.20 & 0.70 & 3.40 & 0.30 & Accepted \\
\hline 8. & $\begin{array}{l}\text { Inadequate teaching and } \\
\text { learning facilities }\end{array}$ & 4.60 & 0.51 & 3.60 & 0.92 & 4.10 & 0.52 & Accepted \\
\hline
\end{tabular}

Source: Field survey: 2013. Mean based on 5 point Likert scale of 5-1 (Very True, True, Somewhat True, Not true \& Not at all)

Table 1 shows weighted means $(\bar{X})$ and standard deviations (SD) of respondents (teachers and parents) on reasons why there is low participation of teachers in enhancement of secondary school quality in Cross River State. The grand mean ranges from 1.23 to 4.15 and SD ranges from 0.16 to 0.91 . Of the 8 reasons advanced for low involvement of teachers in quality assurance, 6 have mean scores above 2.5 which was the level of acceptance. Poor motivation of teachers attracted the strongest reason for low participation of teachers in their paid assignment (4.15). This was followed, in that order, by inadequate school facilities (4.10), unrealistic assessment at primary school (3.40). Inadequate supervision by school inspectors/supervisors (2.85), poor knowledge of subject matter (2.75); and inadequate instructional supervision by principal (2.55). Poor teacher/student relationship (2.15) and low professional qualification of teachers received the least weighted means as reasons for low teachers' participation in quality enhancement.

A close observation of results in Table 1 revealed that teachers opinion differ greatly from parents especially for the advanced reasons that tended to lay blame on teachers. Such reasons are items 2, 3, 4, 5 and 6 . The weighted mean scores of teachers for these five items are quite low compared to mean scores of parents. This indicates that teachers are to blame for their low participation in enhancing quality education.

The finding on teachers inadequate knowledge of subject matter is in line with FRN (2004) that you cannot give what you do not have; Parkay and Standford, (2004)that many teachers do not know the most appropriate ways to present the subject matter to students through analogies, metaphors, experiments, demonstrations and illustrations.

\section{Research question 2}

Why is there low participation of parents in quality enhancement of secondary education in Cross River State? 
Table 2: Weighted mean scores $(\bar{X})$ and standard deviation $(S D)$ of teachers and parents opinions on reasons for low participation of parents in quality enhancement of secondary education in CRS (No. of teachers $=870$ and No of parents $=100$ ).

\begin{tabular}{|l|l|ll|ll|ll|l|}
\hline S/No & Reasons & \multicolumn{2}{|l|}{ Teacher } & \multicolumn{2}{l|}{ Parents } & \multicolumn{2}{l|}{ Grand } & Decision \\
\cline { 3 - 8 } & & $\bar{X}$ & SD & $\bar{X}$ & SD & $\bar{X}$ & SD & \\
\hline 9. & $\begin{array}{l}\text { Parent have many } \\
\text { children in school }\end{array}$ & 3.20 & 0.68 & 3.40 & 0.70 & 3.30 & 0.79 & Accepted \\
\hline 10. & $\begin{array}{l}\text { Parents/children poor } \\
\text { moral attitude at home. }\end{array}$ & 3.60 & 2.67 & 2.00 & 0.90 & 2.80 & 0.79 & Accepted \\
\hline 11. & $\begin{array}{l}\text { Hostile relationship } \\
\text { between teachers and } \\
\text { parents }\end{array}$ & 2.10 & 0.93 & 2.40 & 0.89 & 2.25 & 0.76 & $\begin{array}{l}\text { Not } \\
\text { Accepted }\end{array}$ \\
\hline 12. & $\begin{array}{l}\text { Low socio-economic } \\
\text { status of parents }\end{array}$ & 3.40 & 0.70 & 3.00 & 0.82 & 3.20 & 0.76 & Accepted \\
\hline 13. & $\begin{array}{l}\text { Parents are so occupied } \\
\text { in other activities }\end{array}$ & 3.30 & 0.76 & 3.60 & 0.80 & 3.45 & 0.81 & Accepted \\
\hline 14. & $\begin{array}{l}\text { Child's education is a } \\
\text { sole responsibility of } \\
\text { teachers }\end{array}$ & 0.50 & 0.92 & 2.0 & 0.93 & 1.25 & 0.92 & Not Accepted \\
\hline
\end{tabular}

Source: Field survey: 2013. Mean based on 5 point Likert scale of 5-1 (Very True, True, Somewhat True, Not true \& Not at all)

The analyses of data in Table 2 suggest that parents have low participation in their children education as a result of a general high cost of living in the country. This has caused parents to over occupy themselves in other economic activities $(\bar{X}=3.45 ; \mathrm{SD}=0.81)$ at the expense of their children education, parents tend to bite off more than they can chew, that is, they have many children they can successful train $(x=3.30 ; S D=0.79)$ and socio-economic status of parents $(x=3.20 ; S D=0.76)$. The analyses also revealed that parents/children poor moral attitude at home $(x=2.80 ; S D=0.78)$ is responsible for low participation in education.

This finding is similar to the results of a study by Abubaka and Lawan (2011) that may parents in Nigeria do not participate fully in the enrolment of their youths in skill Acquisition Training Schemes.

\section{Research question 3}

What is responsible for low participation of communities in quality enhancement of secondary education in Cross River State?

Table 3: shows the weighted mean scores $(\bar{X})$ and Standard Deviations (SD) of teachers and parents opinions on reasons for low participation of communities in quality enhancement of secondary education in CRS (No of teachers $=870$ and parents $=100$ ).

\begin{tabular}{|c|c|c|c|c|c|c|c|c|}
\hline \multirow[t]{2}{*}{ S/No } & \multirow[t]{2}{*}{ Reasons } & \multicolumn{2}{|c|}{ Teacher } & \multicolumn{2}{|c|}{ Parents } & \multicolumn{2}{|c|}{ Grand } & \multirow[t]{2}{*}{ Decision } \\
\hline & & $\bar{X}$ & SD & $\overline{\bar{X}}$ & SD & $\overline{\bar{X}}$ & SD & \\
\hline 15. & $\begin{array}{l}\text { Return on educational } \\
\text { investment comes to } \\
\text { slow }\end{array}$ & 3.68 & 0.71 & 3.50 & 0.78 & 3.59 & 0.75 & Accepted \\
\hline 16. & $\begin{array}{l}\text { High unemployed rate of } \\
\text { school graduates }\end{array}$ & 4.50 & 0.60 & 4.56 & 0.66 & 4.53 & 0.61 & Accepted \\
\hline 17. & $\begin{array}{l}\text { School drop-outs do not } \\
\text { receive enough } \\
\text { condemnation }\end{array}$ & 3.40 & 0.76 & 2.40 & 0.80 & 2.90 & 0.90 & Accepted \\
\hline 18. & $\begin{array}{l}\text { High } \\
\text { qualification is not ademic } \\
\text { act }\end{array}$ & 2.56 & 0.81 & 3.00 & 0.67 & 2.78 & 0.85 & Accepted \\
\hline
\end{tabular}




\begin{tabular}{|l|l|ll|ll|ll|l|}
\hline & $\begin{array}{l}\text { lriterion for award of } \\
\text { government contract and } \\
\text { elective position }\end{array}$ & & & & & & \\
\hline 19. & $\begin{array}{l}\text { Low recognition of } \\
\text { people with high records } \\
\text { of academic achievement }\end{array}$ & 3.40 & 0.70 & 2.60 & 0.90 & 3.00 & 0.89 & Accepted \\
\hline 20. & $\begin{array}{l}\text { High poverty level in the } \\
\text { society }\end{array}$ & 4.60 & 0.60 & 4.50 & 0.56 & 4.55 & 0.61 & Accepted \\
\hline
\end{tabular}

Source: Field survey: 2013. Mean based on 5 point Likert scale of 5-1 (Very True, True, Somewhat True, Not true \& Not at all)

The analyses in Table 3 reveal that low level of participation in secondary education quality enhancement was due to hardship associated with ailing/dwindling state economy. The expressed opinions are arranged hierarchically to indicate their magnitude. High poverty level in the society $(\bar{X}=4.55 ; \mathrm{SD}=0.61)$, high unemployment rate $(\bar{X}=4.53$; SD 0.61$)$ and return of investment does not come fast $(\bar{X}=3.59$; $S D=0.75)$. Others are social factors, example, low recognition of people with high records of academic achievements $(\bar{X}=3.00, \mathrm{SD}=0.89)$, school drop-outs do not receive enough condemnation ( $\bar{X}=2.90, \mathrm{SD}=0.90)$ and high academic qualification is not a criterion for award of government contract and elective positions $(\bar{X}=2.78 ; \mathrm{SD}=0.85)$. The social or ethical factors are in support of the statement by Olugbile (2013) that people who have no moral value, no matter how highly placed, should not be celebrated.

\section{FINDINGS}

The data analyzed in Tables 1-3 revealed that low participation of teachers, parents and communities in quality enhancement of secondary education in Cross River State is caused by

\section{Teachers:}

a. Teachers are poorly motivated by respective agencies.

b. Teaching and learning facilities are inadequate in schools.

c. Pupils in primary schools are not properly assessed, making placement and teaching in the next level difficult.

d. Teachers have poor knowledge of subject matter and so cannot effectively deliver required message.

e. Principals and supervisors/inspectors of schools do not religious monitor classroom instruction and general school supervision respectively.

2. Parents:

a. Parents have many children to cope with in schools in the face of ailing economy.

b. Socioeconomic status of parents is low.

c. Parents appear to be too busy and therefore have little or no time to monitor the school activities of their children.

d. Parents themselves are not morally upright and so cannot give what they do not have.

\section{3) Communities}

a. The dwindling national economy which result in graduate unemployment weakens participants

b. A reasonable proportion of the society tends to have little or no value for high academic records.

c. The society tends to honour people with questionable character by recognizing rich persons who have low moral/ethical values.

\section{RECOMMENDATIONS}

To get out of the wood of low participation of teachers, parents and communities in quality enhancement of secondary education, efforts should be made to improve the quality of instruction given in teacher training institutions. This will reduce quacks and uncommitted people who dominate the profession.

Priority should be given to primary school teachers with particular emphasis on pupils' continuous assessment records which very often are unreliable and unrealistic. This is so as primary education is regarded as the bedrock of any education system.

Practicing teachers should be given adequate opportunity to update knowledge through in-service programmes in tertiary 
institutions and to attend other staff development programmes. This will serve as incentive and therefore makes the profession more attractive.

There should be more enlightenment programme for parents and the general public to abhor cheating tendency among themselves and their children. Moral education should therefore be encouraged.

School dropout syndrome, the 'get rich quickly' and the 'end justified' the means' attitude of people should be discouraged this could be done by avoiding celebration of icons with known questionable characters.

Government should introduce and fully enforce free education upto senior school certificate level in the state. This will hopefully reduce the burden of harsh economy on the people.

Family planning should be made compulsory to people of child bearing age, regulate the spacing and number of children from a woman and from a man.

\section{REFERENCES}

Abubakar, A. N and Lawan, A. B., 2011. Assessment of emerging roles and responsibilities of community toward vocational skill acquisition. Journal of Teachers Perspective (JOTEP). 5, (1): July, p. 119-131.

Brunner, J. S., 1966. Toward a theory of instruction. New York: Norton.

Eqwuasi, P. I and Okoro, C. C., 2011. Restructuring the quality of teachers for the psychological well being of Nigerian job seekers. Journal of Teachers Perspective (JOTEP), 5, (1): July, p. 4348.

Ereyimwen, A. A and Ezeanah, U., 2011. Proper evaluation, quality control and quality education - catalyst for job creation. Journal of Teachers Perspective (JOTEP), 5(1) July p. 142-147.

Essien, I., 2006. Influence of parental modeling on students' aggressiveness. Journal of Research and Educational Development (JORED), 1, (1\&2): June p. 146-151.
Etuk, M. B., 2002. Demographic variables and teachers' performance in secondary school in Akwa Ibom State. Unpublished Master's Thesis, Faculty of Education, University of Uyo.

Idiong, B. U., 2001. The code of ethics for the teaching profession in D. N. Umoren \& C. O. Ogbodo (Eds.). A handbook on teaching profession in Nigeria, Uyo: Guidepost Publishers 61-70.

Isangedighi, A. J., 2007. Child psychology development and education. Calabar: Eti Nwa Associates

National Teachers Institute (NTI)., 2000. NCE/DLs course book education cycle 2 .

Olugbile, S., 2013. The Punch Tuesday 16, July, p. 46.

Ornstein, A. C and Levine, D. U., 2006. Foundations of education. $9^{\text {th }}$ Ed. Boston, New York: Houghton Mifflin.

Puyate, S. T., 2008. Constraint to the effective implementation of vocational education programme in private secondary schools in Port Harcourt Local Government Area. Asia-Pacific Journal of Cooperative Education. 9, (1): 59-71.

Scheerens, J., 2000. Improving school effectiveness. Fundamentals of educational planning. Series - No. 68 United Nations Educational Scientific and Cultural Organization (UNESCO) Paris from information@llep.unesco.org 